\title{
Division and Death Rates of Salmonella typhimurium Inside Macrophages: Use of Penicillin as a Probe
}

\author{
By D. B. LOWRIE, V. R. ABER AND M. E. W. CARROL \\ $M R C$ Unit for Laboratory Studies of Tuberculosis, \\ Royal Postgraduate Medical School, Du Cane Road, London W12 $0 H S$
}

(Received 19 April 1978; revised 14 August 1978)

\begin{abstract}
In mouse peritoneal macrophages infected in vitro with Salmonella typhimurium the number of viable bacteria and the number of stainable bacteria detected by light microscopy both increased at similar rates with a doubling time of more than $1 \mathrm{~h}$. Antibiotics were not present; instead extracellular bacteria were removed by frequently rinsing the cells. The bacterial doubling time in the same medium in the absence of macrophages was about $20 \mathrm{~min}$.

Penicillin added to macrophage monolayers rapidly entered the macrophages, reaching a diffusion equilibrium. The penicillin-induced bacterial death rate appeared to depend on the bacterial division rate as well as on the penicillin concentration. These properties of penicillin were used to monitor intracellular bacterial division and death rates. The results indicated that intracellular killing, with the disappearance of stainable bacteria, did not contribute to the extended doubling time in macrophages. It was concluded that the intracellular environment of the bacteria was probably growth inhibitory but not bactericidal.
\end{abstract}

\section{INTRODUCTION}

Whether salmonellae increase or decline in number within macrophages after phagocytosis, a factor crucial to the outcome of infection with these facultative intracellular parasites (Jenkin \& Rowley, 1963; Blanden et al., 1966), depends on the balance between bacterial division and death rates in the intracellular environment. Studies with macrophages in vitro show that virulent salmonellae are more capable than avirulent organisms of increasing intracellularly (Furness, 1958; Furness \& Ferreira, 1959; Jenkin \& Benacerraf, 1960) and that macrophages from immune animals are better able to restrict intracellular proliferation than those from susceptible animals (Jenkin \& Benacerraf, 1960; Blanden, 1968; Maier \& Oels, 1972). However, virulence might equate with either superior resistance to intracellular bactericidal mechanisms, or to faster multiplication on the nutrients available within the cell, or both. Similarly, immunity might depend on greater intracellular bactericidal power, or greater ability of macrophages to restrict bacterial nutrient availability, or both. To distinguish between these possibilities, estimates of both the intracellular division rate and the death rate are necessary. Once these are made, the factors controlling intracellular microbial growth might be more readily identified.

In principle, division and death rates may be calculated from direct measurements of changes in the numbers of living and of total (living plus dead) bacteria (Rees \& Hart, 1961). For most bacterial species, however, dead intracellular bacteria cannot be assumed to accumulate as fast as they arise; they tend to disappear at unknown rates, both by autolysis and by digestion in the cell's lysosomal apparatus. We have examined an alternative approach which uses the penicillin-induced death rate to estimate division and death 
rates in the absence of penicillin and which involves measuring changes only in the viable fraction of the intracellular population.

Penicillins kill only multiplying bacteria (Hobby et al., 1942; Bigger, 1944), by interfering with wall synthesis (Frère, 1977; Ghuysen, 1977). So the rate of penicillin-induced death at a given penicillin concentration should reflect the rate at which new wall is required. This in turn will be homeostatically linked to the division rate. Hence, the induced death rate will depend on the division rate. If the relationship between these rates is known, and assuming that no other factors are involved, then values may be calculated for simultaneous division and death rates occurring in a penicillin-free environment after merely measuring the overall rates of change of viable population in the presence and absence of penicillin.

We have measured the penicillin-induced death rate of Salmonella typhimurium and found it to be dependent on the division rate as well as the penicillin concentration. We found that penicillin concentrations equilibrated between the intra- and extracellular environment of the macrophages and used these findings to show that the macrophages did not kill the intracellular bacteria but markedly reduced their division rate.

\section{METHODS}

Bacteria. The moderately virulent mouse pathogenic Salmonella typhimurium strain LT2 (Valtonen, 1970) was donated by Dr R. W. Hedges. The organism was grown at $37^{\circ} \mathrm{C}$ in a medium containing: $\mathrm{NH}_{4} \mathrm{Cl}$, $100 \mathrm{~mm}$; glucose, $56 \mathrm{~mm} ; \mathrm{NaH}_{2} \mathrm{PO}_{4}, 10 \mathrm{mM} ; \mathrm{KCl}, 10 \mathrm{~mm} ; \mathrm{MgCl}_{2}, 5 \mathrm{~mm}$; citric acid, $2 \mathrm{~mm} ; \mathrm{Na}_{2} \mathrm{SO}_{4}, 2 \mathrm{mM}$; $\mathrm{CaCl}_{2}, 250 \mu \mathrm{M} ; \mathrm{Na}_{2} \mathrm{MoO}_{4}, 0.1 \mu \mathrm{M}$; trace metal solution, $0.5 \%$ (v/v). The trace metal solution contained: $\mathrm{Fe}^{3+}, 20 \mathrm{~mm} ; \mathrm{Mn}^{2+}, 10 \mathrm{~mm} ; \mathrm{Zn}^{2+}, 5 \mathrm{~mm} ; \mathrm{Co}^{2+}, 2 \mathrm{~mm} ; \mathrm{Cu}^{2+}, 1 \mathrm{~mm}$, as chloride salts, and $\mathrm{H}_{2} \mathrm{BO}_{4}, 1 \mathrm{~mm}$. Bacteria for phagocytosis by macrophages were taken from a late-exponential phase (glucose-limited) culture, centrifuged at $1800 \mathrm{~g}$ for $15 \mathrm{~min}$ at $4^{\circ} \mathrm{C}$, washed in Hanks' balanced salt solution (HSS; $2 \times 10 \mathrm{mI}$ ) by repeated centrifugation and finally suspended at a concentration of $0.2 \times 10^{7}$ to $2 \times 10^{7}$ bacteria ml ${ }^{-1}$ in phagocytosis medium, i.e. HSS containing $2.5 \%(\mathrm{v} / \mathrm{v})$ newborn calf serum (Gibco-Biocult, Paisley, Scotland). Glutaraldehyde-killed bacteria were prepared by resuspending a centrifuged culture in $10 \mathrm{ml}$ icecold $2.5 \%(\mathrm{v} / \mathrm{v})$ glutaraldehyde for $10 \mathrm{~min}$ and washing the bacteria with $0.88 \mathrm{M}$-sucrose $(2 \times 10 \mathrm{ml})$ and then HSS $(2 \times 10 \mathrm{ml})$ by centrifugation. Counts of colony-forming units (c.f.u.) on blood agar typically showed 80 and $0 \%$ viability of suspensions of living and killed bacteria, respectively.

Macrophages. Peritoneal cells were obtained from 20 to $30 \mathrm{~g}$ female mice of the albino CFLP outbred strain (Anglia Laboratory Animals, Alconbury, Huntingdon PE18 6ES). Mice were killed by cervical dislocation, the abdominal skin was reflected and $3 \mathrm{ml}$ tissue culture medium NCTC 109 (Gibco-Biocult) containing $5 \mathrm{U}$ heparin $\mathrm{ml}^{-1}$ were injected intraperitoneally from a syringe with a 21 gauge needle. The peritoneal contents were briefly agitated without withdrawing the needle and then the medium and the suspended cells were drawn into the syringe. Pooled cells from about 40 mice were distributed as $3.5 \mathrm{ml}$ portions, con taining $2 \times 10^{6}$ cells ml ${ }^{-1}$, into $5 \mathrm{~cm}$ plastic Petri dishes (Nunc; Gibco Biocult) and incubated for $2 \mathrm{~h}$ at $37^{\circ} \mathrm{C}$ to allow cell attachment. The dishes were then gently agitated and the medium was removed and replaced with a maintenance medium (MM) which contained: NCTC 109, $50 \%$ (v/v); horse serum (Gibco Biocult; heat-inactivated at $56{ }^{\circ} \mathrm{C}$ for $20 \mathrm{~min}$ ), $40 \%(\mathrm{v} / \mathrm{v})$; bovine embryo extract (Difco; diluted fivefold with NCTC 109), $10 \%$ (v/v); liver fraction L (Micro-Bio Laboratories, London), $1 \mathrm{mg} \mathrm{ml}^{-1}$;

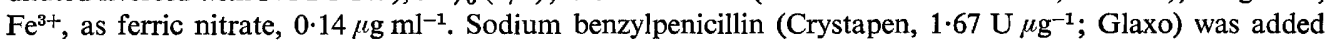
at $60 \mu \mathrm{g} \mathrm{ml}^{-1}$. The resultant macrophage monolayers were maintained at $37{ }^{\circ} \mathrm{C}$ in an atmosphere of $5 \%$ $\mathrm{CO}_{2}$ in air and the medium was removed after 3 to $4 \mathrm{~d}$ and replaced with fresh MM (antibiotic-free, unless otherwise stated).

Infection and maintenance of infected macrophages. Between 7 and $14 \mathrm{~d}$ after establishment of the monolayers, MM was removed from the dishes and the monolayers were rinsed with HSS containing $0.007 \%$ (w/v) sodium bicarbonate at $37^{\circ} \mathrm{C}$ then overlaid with $3 \mathrm{ml}$ of $S$. typhimurium suspension in phagocytosis medium and incubated at $37^{\circ} \mathrm{C}$ for $2 \mathrm{~h}$. The monolayers were then vigorously rinsed with warm HSS $(2 \times 3 \mathrm{ml})$, containing $0.035 \%$ bicarbonate, to remove free bacteria. Fresh MM $(3.5 \mathrm{ml})$ was put in the dishes and the monolayers were further incubated for up to $3 \mathrm{~h}$ at $37^{\circ} \mathrm{C}$ in a $5 \% \mathrm{CO}_{2}$ atmosphere. At hourly intervals the MM was withdrawn and the monolayers were rinsed with HSS $(2 \times 3 \mathrm{ml})$ containing $0.035 \%$ bicarbonate, to remove monolayer-free bacteria. Fresh MM was then put on the monolayers. in experiments to test the effect of penicillin on the fate of bacteria in the macrophages, monolayers were 
exposed to penicillin at a concentration of $0,20,60,180$ or $540 \mu \mathrm{g} \mathrm{ml}^{-1}$ in MM, both for 4 to $11 \mathrm{~d}$ before phagocytosis and during post-phagocytosis incubation. HSS used to rinse these monolayers contained penicillin at the same concentration as in the MM. Stock penicillin solutions were prepared on the day of use and kept on ice.

Immediately after phagocytosis and at intervals during subsequent incubation, the total number of bacteria present in the monolayers and the numbers of monolayer-associated and monolayer-free live bacteria in the dishes were assessed.

Estimation of live bacteria in macrophage cultures. Used MM removed from replicate monolayers was stored on ice for subsequent estimation of monolayer-free bacteria. Macrophages were harvested from HSS-rinsed monolayers into $1.5 \mathrm{ml}$ ice-cold HSS by scraping with a silicone rubber 'policeman'. Each dish was then rinsed with $1.5 \mathrm{ml}$ HSS and the rinse and harvest suspensions were pooled for assay of monolayer-associated bacteria. The pooled suspensions and the spent maintenance medium were exposed to $15 \mathrm{~s}$ ultrasonication using a Biosonik (Bronwill Scientific Co., Rochester, N.Y., U.S.A.) microprobe at $60 \mathrm{~W}$ output to disrupt intact macrophages. Serial dilutions were then made in $0.9 \%(\mathrm{w} / \mathrm{v}) \mathrm{NaCl}$ and c.f.u. were assessed on blood agar. Preliminary experiments showed that ultrasonication for up to $20 \mathrm{~s}$ caused no decrease in c.f.u. Counts of monolayer-associated and monolayer-free bacteria were expressed as the mean number per monolayer macrophage, calculated from estimates of the DNA (Giles \& Myers, 1965) recovered from the monolayers on the basis of $7.5 \mu \mathrm{g}$ DNA in $10^{6}$ macrophages. The contribution of bacterial DNA $\left(1.0 \mu \mathrm{g}\right.$ in $10^{8}$ bacteria) to the total DNA in infected monolayers was negligible.

Estimation of total monolayer-associated bacteria. Replicate monolayers were air-dried, fixed in methanol and Giemsa-stained. Random fields of view were examined by light microscopy until a total of 200 macrophages per monolayer had been counted. The numbers of macrophages containing 0,1 to 3,4 to 10,11 to 20 or $>20$ bacteria were recorded and the mean number of bacteria per macrophage was calculated assuming $0,2,7 \cdot 5,15 \cdot 5$ and 25 per cell in the respective score groups.

Effect of bacterial growthrate on susceptibility to penicillin. Test-tubes $(10 \times 75 \mathrm{~mm})$ containing 0 to $540 \mu \mathrm{g}$ penicillin in $0.9 \mathrm{ml} \mathrm{MM}$ were pre-warmed to either 27 or $37^{\circ} \mathrm{C}$ and inoculated with $2 \times 10^{5}$ to $3 \times 10^{5}$ c.f.u. in $0.1 \mathrm{ml}$ of a mid-exponential phase culture of bacteria growing in $\mathrm{MM}$ at the same temperature. Incubation of the inoculated media was continued for $3 \mathrm{~h}$ and at intervals $0.1 \mathrm{ml}$ samples were removed, serially diluted in $0.9 \%(\mathrm{w} / \mathrm{v}) \mathrm{NaCl}$ and the numbers of c.f.u. were determined on blood agar.

Calculation of bacterial doubling time or half-life. The bacterial doubling time or half-life was calculated as $0 \cdot 301 / \mathrm{M}$, where $\mathrm{M}$ is the estimated slope of the fitted regression line of $\log _{10}$ (number of viable bacteria) against time. The standard error of the bacterial doubling time or half-life was estimated as $\left(0 \cdot 301 \times S_{M}\right) / M^{2}$, where $S_{\mathrm{M}}$ is the standard error of the slope of the regression line, calculated from a least-squares analysis. The standard error of the ratio of two slopes $\left(M_{1} / M_{2}\right)$ was estimated as $\left(1 / M_{2}\right) \sqrt{ }\left[S_{\mathbb{M}_{1}}^{2}+S_{\mathbb{M}_{2}}^{2}\left(M_{1}^{2} / M_{2}^{2}\right)\right]$ where $M_{1}, S_{M_{1}}$ and $M_{2}, S_{M_{2}}$ are, respectively, the slope and standard error of the slope of the two regression lines of $\log _{10}$ (number of viable bacteria) against time (Armitage, 1971).

Macrophage permeability to penicillin. Medium was aspirated from monolayers which had teen maintained for $12 \mathrm{~d}$ in antibiotic-free MM and then MM $(2 \mathrm{ml})$ containing various concentrations of unlabelled and $\left[{ }^{14} \mathrm{C}\right]$ benzylpenicillin (about $1 \mu \mathrm{Ci} \mathrm{ml}{ }^{-1}$, potassium 6-phenyl-[1-14 $\mathrm{C}$ acetamido penicillinate, $59 \mathrm{mCi}$ $\mathrm{mmol}^{-1}$; The Radiochemical Centre, Amersham) was added. Uptake of ${ }^{14} \mathrm{C}$ was determined at intervals during subsequent incubation $\left(37^{\circ} \mathrm{C}, 5 \% \mathrm{CO}_{2}\right.$ in air). Medium was removed from replicate monolayer dishes, the monolayers were rinsed with ice-cold HSS $(5 \times 2 \mathrm{ml})$, digested in $0.2 \mathrm{M}-\mathrm{NaOH}(2 \times 1 \mathrm{ml})$ and samples from rinse and digest solutions were taken for scintillation counting. Control (cell-free) dishes were processed in parallel with the monolayer dishes. The corresponding rinses of control and monolayer dishes contained similar amounts of radioactivity, indicating that free radioactivity was rinsed out of control and monolayer dishes at the same rate. The amount of cell-associated penicillin was calculated as the amount of radioactivity found in $\mathrm{NaOH}$ digests of rinsed monolayer dishes minus the amount found in $\mathrm{NaOH}$ extracts of rinsed control dishes. ${ }^{14} \mathrm{C}$ efflux from cells previously incubated with $\left[{ }^{14} \mathrm{C}\right]$ penicillin was also assessed. Medium was removed and then $2 \mathrm{ml}$ of warm penicillin-free MM was added. The dishes were incubated and residual cell-associated ${ }^{14} \mathrm{C}$ was assessed at intervals as described above. Representative monolayers were assayed for DNA to estimate the number of cells. In separate experiments the intracellular water space of monolayer macrophages was found, by the method of Kletzien et al. (1975), to be $1.4 \mu 1$ $\left(10^{6} \text { macrophages }\right)^{-1}$. From this relationship intracellular concentrations of penicillin were calculated, assuming all cell-associated penicillin to be free in the intracellular water space.

Ultrastructural demonstration of penicillin-induced damage to intracellular bacteria. Infected monolayers maintained for $3 \mathrm{~h}$ in the presence of penicillin $\left(60 \mu \mathrm{g} \mathrm{m}^{-1}\right)$ were examined by transmission electron microscopy of ultrathin sections as described by Carrol et al. (1979) and the morphological integrity of the intracellular bacteria was assessed. 
Use of penicillin to estimate intracellular division and death rates. The rate of change in the number of viable intracellular bacteria was measured with and without penicillin present in the macrophage maintenance medium. Bacterial division and death rates in the penicillin-free macrophages were then estimated applying the following argument.

Let $b$ be the bacterial division rate, $p$ and $d$ be, respectively, the viable population growth and death rates in the absence of penicillin and $P(C)$ and $D(C)$ the viable population growth rate and the penicillininduced death rate at a concentration $C$ of penicillin [where $P(0)=p, D(0)=0$ ], then

and

$$
p=b-d \text { or } b=p+d
$$

$$
P(C)=b-d-D(C)
$$

Dependence of the induced death rate solely on the division rate and penicillin concentration may be written as

$$
D(C)=b f(C)
$$

where $f$ is some function of $C$. Then equation 2 is equivalent to

$$
P(C)=b[1-f(C)]-d
$$

which, on substituting for equation 1 , becomes

$$
\text { or, on rearrangement, when } f(C) \neq 0, \begin{array}{r}
P(C)=p[1-f(C)]-d f(C) \\
d=\frac{p[1-f(C)]-P(C)}{f(C)}
\end{array}
$$

Hence $d$ and $b$ may be calculated when values of $p, P(C)$ and $f(C)$ are known for some value of $C$.

\section{RESULTS}

Slow increase in bacterial populations inside antibiotic-free macrophages

The number of salmonellae measured in monolayers by light microscopy and by c.f.u. counts increased approximately in parallel after the phagocytosis period. In a typical experiment the doubling times were $2.9 \pm 0.7 \mathrm{~h}$ and $2.3 \pm 0.4 \mathrm{~h}$, respectively (Fig. $1 \mathrm{a}$ ). The ratio of monolayer-free to monolayer-associated live bacteria in the culture dishes was maintained at $<1: 20$ by rinsing the monolayers hourly, so it seemed unlikely that continued phagocytosis of residual extracellularly multiplying bacteria contributed substantially to the increase in monolayer-associated bacteria, although this possibility was not entirely excluded. If macrophages were killing intracellular bacteria, the ratio of numbers of live organisms to total organisms should alter. However, a similar increase in total and viable bacteria does not completely exclude intracellular killing, since a proportion of the bacteria might be not only killed but also rendered non-staining by intracellular digestion. Bacteria killed with glutaraldehyde before phagocytosis disappeared with a half-life of $1.6 \mathrm{~h}$ in macrophages (Fig. 1b).

We investigated intracellular multiplication further by using penicillin to allow measurement of the intracellular division rate.

\section{Penicillin as a probe of bacterial division rate}

To test whether the penicillin-induced death rate was a function of the division rate and penicillin concentration, the effect of temperature on bacterial doubling time and on susceptibility to penicillin was examined (Fig. 2).

At $37^{\circ} \mathrm{C}$ the bacteria multiplied in penicillin-free $\mathrm{MM}$ with a doubling time of $21 \pm 1 \mathrm{~min}$ (Fig. 2a), similar to the minimum doubling time which could be obtained in standard laboratory media at $37^{\circ} \mathrm{C}$. The population growth rate was therefore assumed to equal the division rate in this medium. In the presence of 20 and $60 \mu \mathrm{g}$ penicillin ml-1 the bacterial population declined exponentially, after a short initial lag period, with half-lives of $36 \pm 3$ 


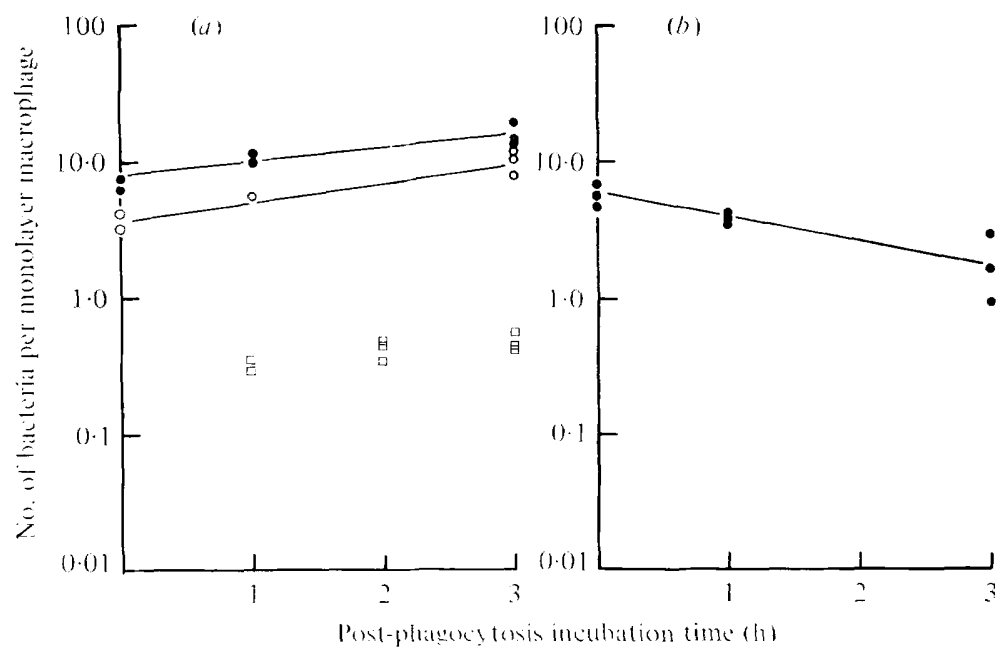

Fig. 1. Post-phagocytosis change in the number of bacteria in penicillin-free macrophage monolayer culture dishes. Maintenance medium was removed, the monolayers were rinsed and the medium was replenished every hour. (a) After phagocytosis of live bacteria the average number of cell-associated bacteria per monolayer macrophage was assessed by light microscopy of fixed and stained monolayers $(O)$ and by c.f.u. and DNA determinations of disrupted monolayers (O). The number of monolayer-free viable bacteria per monolayer macrophage $(\square)$ was calculated from c.f.u. counts on spent maintenance medium. (b) After phagocytosis of glutaraldehyde-killed bacteria the average number of monolayer-associated bacteria per macrophage (O) was assessed as in $(a)$. In both $(a)$ and $(b)$, each point represents an individual monolayer culture dish. Regressions of $\log _{10}$ (number of bacteria) against time were fitted by the least-squares method.

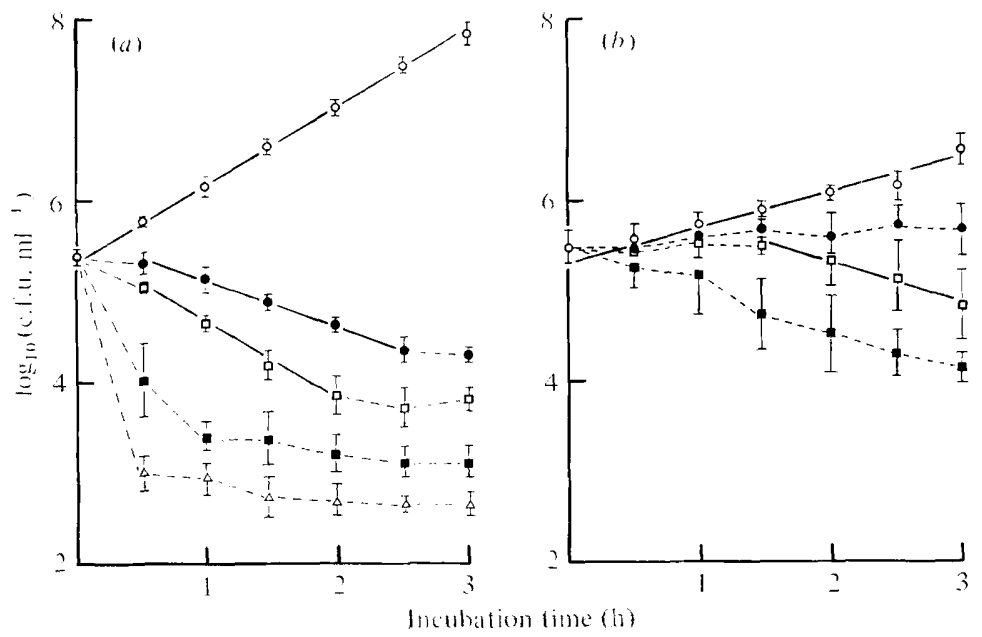

Fig. 2. Effect of bacterial multiplication rate on susceptibility to penicillin. Bacterial viability was assessed at intervals during incubation at $37^{\circ} \mathrm{C}(a)$ and $27^{\circ} \mathrm{C}(b)$ in macrophage maintenance medium which contained $0(\bigcirc), 20(\bigcirc), 60(\square), 180(\boldsymbol{D})$ or $540(\triangle) \mu \mathrm{g}$ benzylpenicillin $\mathrm{ml}^{-1}$. Each condition was tested in duplicate in two experiments and the mean values of the four determinations are shown with their standard deviations. Regressions were fitted by the least-squares method.

$\min$ and $21 \pm 1 \mathrm{~min}$, respectively. With 180 and $540 \mu \mathrm{g}$ penicillin $\mathrm{ml}^{-1}$ the kill was too rapid to permit half-life estimation.

At $27^{\circ} \mathrm{C}$ (Fig. $2 b$ ) the doubling time was about twice that at $37^{\circ} \mathrm{C}(46 \pm 7 \mathrm{~min})$. The effect of penicillin was much more variable at this temperature, both within and between 


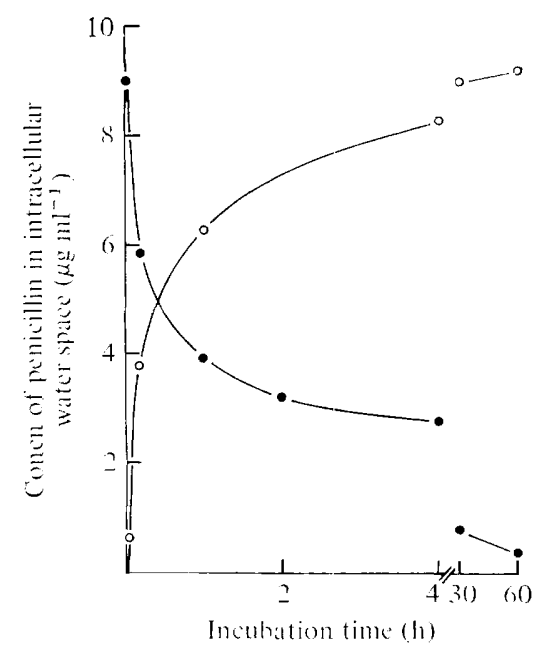

Fig. 3

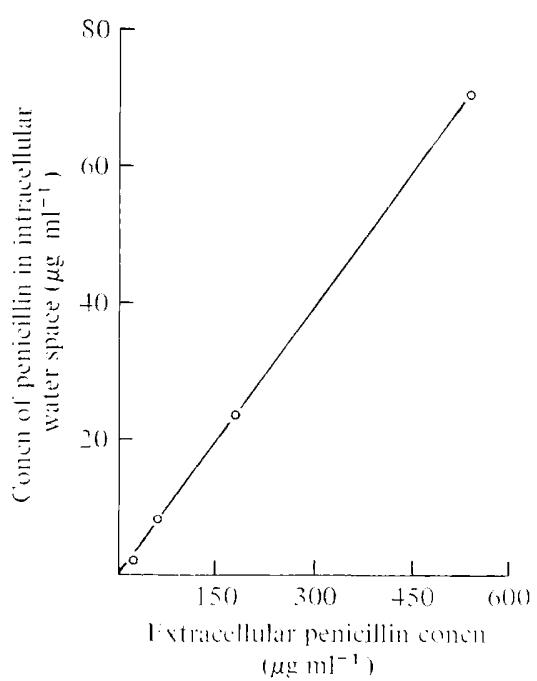

Fig. 4

Fig. 3. Penicillin uptake by macrophages and efflux from previously loaded cells. Uptake (O) was assessed in monolayers which were incubated at $37^{\circ} \mathrm{C}$ in maintenance medium containing $60 \mu \mathrm{g}\left[{ }^{14} \mathrm{C}\right]$ penicillin $\mathrm{ml}^{-1}$. Efflux $(\mathrm{O})$ of $\left[{ }^{14} \mathrm{C}\right]$ penicillin was measured in monolayers which were

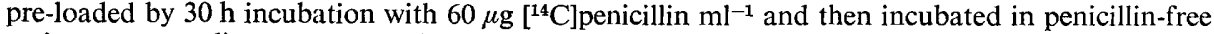
maintenance medium. At intervals monolayers were rinsed, digested in $\mathrm{NaOH}$ and the amount of cell-associated penicillin was estimated by liquid scintillation counting. The results are expressed as intracellular penicillin concentration, calculated using the estimated monolayer intracellular water space (see Methods). Each point represents the mean of duplicate monolayers.

Fig. 4. Penicillin uptake at equilibrium. Cell-associated penicillin was assessed after $30 \mathrm{~h}$ incubation of macrophage monolayers in maintenance medium containing $20,60,180$ and $540 \mu \mathrm{g}$ $\left[{ }^{14} \mathrm{C}\right]$ penicillin $\mathrm{ml}^{-1}$ and expressed as intracellular concentration as in Fig. 3. Each point represents the mean of two or three monolayers.

experiments, so that periods of exponential decline in viability were more difficult to define. Nevertheless with $60 \mu \mathrm{g}$ penicillin $\mathrm{ml}^{-1}$ the half-life was about twice that at $37^{\circ} \mathrm{C}(42 \pm 12$ min compared with $21 \pm 1 \mathrm{~min}$ ).

Penicillin could apparently be used as a probe of the division and death rates occurring in infected macrophages, provided that intracellular concentrations were known.

\section{Penetration of penicillin into macrophages}

Radiotracer studies showed that penicillin rapidly entered the macrophages, reaching equilibrium within a few hours (Fig. 3). The amount of cell-associated $\left[{ }^{14} \mathrm{C}\right]$ penicillin was not decreased by the presence of large amounts of unlabelled penicillin during equilibrium. Hence the amount of penicillin taken up by the macrophages was not limited by the availability of penicillin-binding sites, for which labelled and unlabelled penicillin would compete, and the cell-associated penicillin was considered to be free within the intracellular water space. The apparent intracellular equilibrium concentration was proportional to the extracellular concentration (Fig. 4), but was consistently only about $13 \%$ of the extracellular concentration. This low value was probably due to efflux of intracellular penicillin during the removal, by rinsing, of extracellular penicillin before assay. Efflux was rapid even after such rinsing (Fig. 3). Experiments with metabolic inhibitors (unpublished results) showed that penicillin uptake was essentially energy-independent. It was concluded that the intracellular antibiotic concentration probably equalled that in the surrounding medium. 


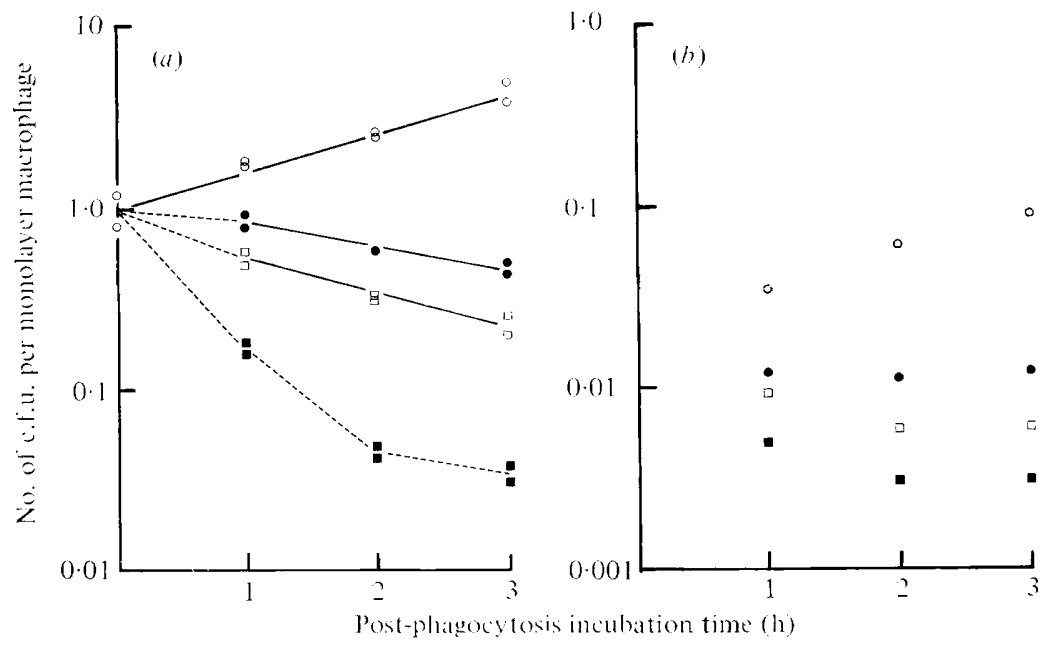

Eig. 5. Effect of penicillin on post-phagocytosis change in bacterial viability in macrophage monolayer culture dishes. Monolayers from the same initial cell pool were maintained, both before and after phagocytosis, in the presence of $0(\bigcirc), 20(\Theta), 60(\square)$ or $180(\mathbb{a}) \mu \mathrm{g}$ benzylpenicillin $\mathrm{ml}^{-1}$. (a) Monolayer-associated bacteria; (b) monolayer-free bacteria in the supernatants from the dishes assayed for $(a)$. Experimental details were as described in Fig. 1 and in the text.

\section{Intracellular division and death rates revealed with penicillin}

The number of live salmonellae declined in monolayers exposed to penicillin (Fig. $5 a$ ). Electron microscopy confirmed the antibacterial activity of intracellular penicillin; many intracellular bacteria showed increased diameter or gaps in the cell envelopes (or both; Fig. 6) in penicillin-treated monolayers. Surface-adherent extracellular bacteria were not seen.

The ratio of the population growth rate in the presence of $60 \mu \mathrm{g}$ penicillin $\mathrm{ml}^{-1}$ to that in the absence of penicillin $(-1 \cdot 11 \pm 0 \cdot 165$ S.E., Fig. $5 a)$ was not significantly different from the ratios observed in experiments with extracellularly multiplying bacteria $(-1.02 \pm$ $0 \cdot 06$, Fig. $2 a ;-0.92 \pm 0.29$, Fig. $2 b$ ) where the penicillin-independent death rate could be assumed to be zero. The same conclusion was reached from experiments using $20 \mu \mathrm{g}$ penicillin $\mathrm{ml}^{-1}$ (Figs $2 a$ and $5 a$ ). These results, together with the previously noted dependence of the penicillin-induced death rate on the division rate and concentration of penicillin, imply that within penicillin-free macrophages the death rate was also essentially zero.

An alternative explanation of the observations would be that continued ingestion of bacteria was exactly cancelling a killing effect of the macrophages. Such an exact balance seemed unlikely. Furthermore the ratio of the number of monolayer-free to the number of monolayer-associated live bacteria was not decreased by the presence of penicillin (Fig. 5). This observation suggested that the monolayer-free bacteria were partially protected from penicillin by being present in a growth-inhibitory environment inside cells which had detached from the monolayer. Such bacteria would not be available for continued phagocytosis. (No loss of monolayer cells was detectable by DNA estimation and possible loss of intracellular bacteria from the monolayer was ignored in calculating intracellular growth rates.) In addition, the proportion of monolayer cells which contained no bacteria did not change significantly $\left(P>0.05 ; \chi^{2}\right.$ test) during post-phagocytosis incubation, further supporting the conclusion that continued phagocytosis was negligible. 


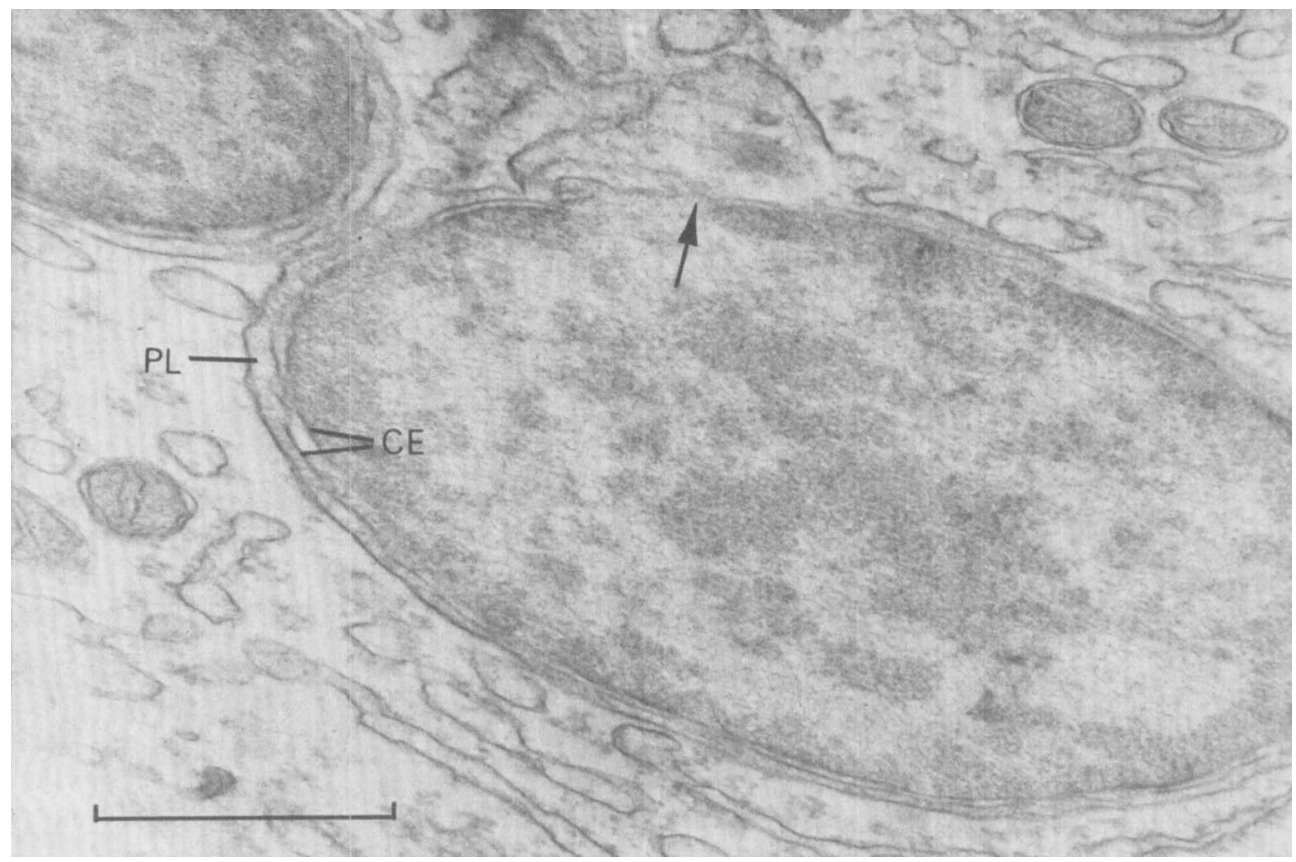

Fig. 6. Electron micrograph of an ultrathin section of a macrophage infected with $S$. typhimurium and maintained in the presence of penicillin $\left(60 \mu \mathrm{g} \mathrm{ml}^{-1}\right)$ for $3 \mathrm{~h}$. Breaks can be seen in the cell envelopes (CE) of the grossly distended bacterium. Extrusion of bacterial contents into the phagolysosome (PL) is occurring (arrow). Bar marker represents $0.5 \mu \mathrm{m}$.

\section{DISCUSSION}

Attention was here confined to the division and death rates of Salmonella typhimurium in macrophages after the ingestion stage of phagocytosis. No conclusions can be drawn about bactericidal events occurring during ingestion, when production of bactericidal hydrogen peroxide is enhanced in mouse peritoneal macrophages (Klebanoff \& Hamon, 1975; Nathan \& Root, 1977).

Analysis of the post-ingestion fate of intracellular bacteria would be confused by continued phagocytosis. This was prevented by frequently rinsing the macrophage monolayers, a technique also used by Kapral \& Shayegani (1959) and Mackaness (1962). The technique appears preferable to that of adding antibiotics which are assumed to be ineffective against intracellular bacteria (Hart, 1974). Observations that bacteria gain protection from antibiotics by intracellular residence (Magoffin \& Spink, 1951; Suter, 1952; Mackaness, 1952) led to widespread adoption of the use of antibiotics such as penicillin and streptomycin to selectively kill extracellular bacteria in vitro (Furness, 1958; Holmes et al., 1966; Alexander \& Good, 1968; Solberg, 1972; Ward et al., 1972; Hsu \& Mayo, 1973; Wilder \& Edberg, 1973). It became clear that these antibiotics could enter phagocytes and kill intracellular bacteria (Richardson \& Holt, 1962; Gröschel \& Jakubowitch, 1967; Cole \& Brostoff, 1975; Veale et al., 1976) and therefore could interfere with estimates of cellular antimicrobial power. We have confirmed early studies by Eagle (1954) that indicated approximately equal concentrations of intra- and extracellular ${ }^{14} \mathrm{C}$-labelled penicillin within $3 \mathrm{~h}$ in tissue culture cell lines. Mandell (1973) failed to find penicillin within human leukocytes incubated with the ${ }^{14} \mathrm{C}$-labelled drug for $2 \mathrm{~h}$, but Veale et al. (1976) found a bactericidal effect of penicillin against gonococci in human leukocytes within $2 \mathrm{~h}$ after drug addition. Such discrepancies might reflect differences both in cell type and in maintenance conditions. 
Several assumptions were made using intracellular penicillin as a probe of division and death rates. The assumption that the penicillin-induced death rate would depend on the division rate was supported by this and other studies of the effect of temperature on penicillin susceptibility (Hobby et al., 1942; Hinks et al., 1977; Wegener et al., 1977). Varying the temperature was not an ideal means of changing the division rate. Some processes involved in penicillin-induced death (e.g. antibiotic penetration, penicillin/target enzyme binding) might differ in temperature sensitivity from those controlling the division rate. Further proof that the penicillin-induced death rate depends on the division rate is desirable. Slow-growing mutants of Escherichia coli showed an enhanced resistance to penicillin (Kamiryo \& Strominger, 1974).

Calculation of intracellular division and death rates from measurements of rates of population change in the presence and absence of penicillin depends on the assumption that any death rate which occurs in the absence of penicillin (the macrophage-induced death rate) is unaffected by the presence of penicillin; the penicillin- and macrophageinduced death rates should be additive. Although the detailed mechanism whereby penicillin kills bacteria remains unknown (Ghuysen, 1977), it seemed likely that any bactericidal products of the macrophages attack different targets from penicillin. Nevertheless, penicillininduced wall defects might facilitate access of macrophage products to their target sites and result in synergism. In the present study this did not occur; no bactericidal effect of the macrophages could be discerned, even in the presence of penicillin. Since the intracellular bacteria were almost entirely confined within lysosomes (Carrol et al., 1979) and so were exposed to hydrolytic enzymes, the lethal effect of penicillin evidently precedes, or is simultaneous to, the development of such wall defects as might allow a lethal effect of lysosomal contents. Reports of apparent bactericidal synergism between leukocytes and penicillin or streptomycin (Alexander \& Good, 1968) may be explained by demonstrations that phagocytosis can be enhanced by antibiotics (Seneca \& Peer, 1966; Adam et al., 1972).

We have assumed penicillin to be equally active in the intra- and extracellular environments, but macrophage phagolysosomes probably have acidic contents (Jensen \& Bainton, 1973; Klebanoff \& Hamon, 1975). Bacteria have been found to be protected against the lytic but not the growth inhibitory effects of benzylpenicillin when they were exposed during growth at pH 5 to 6 (Lopez et al., 1976; Goodell et al., 1976; Wegener et al., 1977). The protective effect of low $\mathrm{pH}$ was ascribed to a decreased activity of autolytic enzymes or an increased stability of bacterial membranes at low pH (Goodell et al., 1976; Wegener et al., 1977). Therefore the impaired bactericidal effect of penicillin against intracellular $S$. typhimurium observed here might result not only from a decreased division rate but also from an acid-enhanced resistance to lysis. However, such resistance in $E$. coli and in pneumococci has been shown to be accompanied by a decreased killing only when low pH conditions were maintained throughout viability assay procedures (Lopez et al., 1976; Goodell et al., 1976); acid-induced stability was labile. We assessed loss of intracellular viability at neutral $\mathrm{pH}$. Hence, even if protection by increased stability at low $\mathrm{pH}$ did occur in the intact macrophages, the phenomenon would probably not interfere with the penicillin probe technique.

Our conclusions based on the use of penicillin to reveal intracellular division and death rates can only be regarded as tentative. Nevertheless, both the penicillin probe and the counts of viable versus total intracellular organisms indicate that the intracellular (penicillinabsent) death rate was zero. Considered together the results of these two indirect measures strongly indicate slow multiplication and no simultaneous killing of the intracellular bacteria.

The fate of $S$. typhimurium LT2 in the macrophage monolayers seems similar to its fate in the spleens of intravenously infected mice. Maw \& Meynell (1968), by using a segregating non-replicating genetic marker to probe intrasplenic division and death rates, found slow division rates, equivalent to one division in 5 to $10 \mathrm{~h}$, which were accompanied by even 
slower death rates, equivalent to half-lives of 7 to $16 \mathrm{~h}$. In the present study with macrophage monolayers, intracellular bacterial division was also markedly inhibited, although to a lesser extent (one division in 1.5 to $2.5 \mathrm{~h}$ ), and no killing was detectable. Thus splenic macrophages in vivo and peritoneal macrophages in vitro share the property of being able to restrict the rate of bacterial division while having poor capacity to kill the ingested organisms.

Many species of pathogenic facultatively intracellular bacteria are sensitive to penicillin, so the technique described here might be generally useful in studies of microbial viability changes in leukocytes in vitro. By this means the relation of bacterial division or death rates to virulence or cellular immunity might be assessed.

The authors thank Professor D. A. Mitchison for helpful criticism and Professor A. P. Waterson for providing facilities for electron microscopy.

\section{REFERENCES}

Adam, D., Staber, F., Belohradsky, B. H. \& MARGET, W. (1972). Effect of dihydrostreptomycin on phagocytosis of mouse-peritoneal macrophages in vitro. Infection and Immunity 5, 537541.

Alexander, J. W. \& Good, R. A. (1968). Effect of antibiotics on the bactericidal activity of human leukocytes. Journal of Laboratory and Clinical Medicine 71, 971-983.

Armitage, P. (1971). Statistical Methods in Medical Research, 1st edn, pp. 97, 159. Oxford: Blackwell Scientific Publications.

Bigger, J. W. (1944). Treatment of staphylococcal infections with penicillin by intermittent sterilisation. Lancet ii, 497-500.

BLANDEN, R. V. (1968). Modification of macrophage function. Journal of the Reticuloendothelial Society 5, 179-202.

Blanden, R. V., Mackaness, G. B. \& Collins, F. M. (1966). Mechanisms of acquired resistance in mouse typhoid. Journal of Experimental Medicine 124, 585-600.

Carrol, M. E. W., JacketT, P. S., Aber, V. R. \& Lowrie, D. B. (1979). Phagolysosome formation, cyclic adenosine $3^{\prime}: 5^{\prime}$-monophosphate and the fate of Salmonella typhimurium within mouse peritoneal macrophages. Journal of General Microbiology 110, 421-429.

Cole, P. \& Brostopf, J. (1975). Intracellular killing of Listeria monocytogenes by activated macrophages (Mackaness system) is due to antibiotic. Nature, London 256, 515-517.

EAGLE, H. (1954). The binding of penicillin in relation to its cytotoxic action. III. The binding of penicillin by mammalian cells in tissue culture (HeLa and L strains). Journal of Experimental Medicine 100, 117-124.

Frère, J.-M. (1977). Mechanism of action of $\beta$ lactam antibiotics at the molecular level. Biochemical Pharmacology 26, 2203-2210.

FuRNess, G. (1958). Interaction between Salmonella typhimurium and phagocytic cells in tissue culture. Journal of Infectious Diseases 103, 272-277.

Furness, G. \& Ferreira, I. (1959). The role of macrophages in natural immunity to salmonellae. Journal of Infectious Diseases 104, 203-206.
GHuYSEN, J.-M. (1977). The concept of the penicillin target from 1965 until today. Journal of General Microbiology 101, 13-33.

GILES, K. W. \& MYers, A. (1965). An improved diphenylamine method for the estimation of deoxyribonucleic acid. Nature, London 206, 93.

Goodell, E. W., Lopez, R. \& Tomasz, A. (1976). Suppression of the lytic effect of $\beta$-lactams on Escherichia coli and other bacteria. Proceedings of the National Academy of Sciences of the United States of America 73, 3293-3297.

Gröschel, D. \& JAKUbowitch, R. (1967). Use of ampicillin instead of streptomycin in Salmonellainfected mouse peritoneal macrophage cultures. Journal of Bacteriology 93, 1199-1200.

HART, P. D'A. (1974). Critical approach to the technique of assessment of antibacterial effects of activated mouse peritoneal macrophages. In Activation of Macrophages, pp. 131-136. Edited by W.-H. Wagner \& H. Hahn. Amsterdam and New York: Excerpta Medica and American Elsevier.

Hinks, E. T., Daneo-Moore, L. \& Braverman, S. (1977). Temperature effects on minimum inhibitory and bactericidal concentrations of cell wall antibiotics in Streptococcus faecalis. Antimicrobial:Agents and Chemotherapy 12, 281283.

Hobby, G. L., Meyer, K. \& Chaffee, E. (1942). Observations on the mechanism of action of penicillin. Proceedings of the Society for Experimental Biology and Medicine 50, 281-285.

Holmes, B., Quie, P. G., Windhorst, D. B., Pollara, B. \& Good, R. A. (1966). Protection of phagocytised bacteria from the killing action of antibiotics. Nature, London 210, 1131-1132.

Hsu, H. S. \& MAYo, D. R. (1973). Interactions between macrophages of guinea pigs and salmonellae. III. Bactericidal action and cytophilic antibodies of macrophages of infected guinea pigs. Infection and Immunity 8, 165-172.

JeNkIN, C. R. \& BenACERRAF, B. (1960). In vitro studies on the interaction between mouse peritoneal macrophages and strains of salmonella and Escherichia coli. Journal of Experimental Medicine 112, 403-417. 
JeNKIN, C. R. \& Rowley, D. (1963). Basis for immunity to typhoid in mice and the question of 'cellular immunity'. Bacteriological Reviews 27, 391-404.

Jensen, M. S. \& Bainton, D. F. (1973). Temporal changes in $\mathrm{pH}$ within the phagocytic vacuole of the polymorphonuclear neutrophilic leukocyte. Journal of Cell Biology 56, 379-388.

Kamiryo, T. \& Strominger, J. L. (1974). Penicillinresistant temperature-sensitive mutants of Escherichia coli which synthesise hypo- or hyper-crosslinked peptidoglycan. Journal of Bacteriology 117, 568-577.

Kapral, F. A. \& Shayegani, M. G. (1959). Intracellular survival of staphylococci. Journal of Experimental Medicine 110, 123-138.

Klebanoff, S. J. \& Hamon, C. B. (1975). Antimicrobial systems of mononuclear phagocytes. In Mononuclear Phagocytes in Immunity, Infection and Pathology, pp. 507-529. Edited by R. van Furth. Oxford: Blackwell Scientific Publications.

Kleitzien, R. F., Pariza, M. W., Becker, J. E. \& Potter, V.R. (1975). A method using 3-Omethyl-D-glucose and phloretin for the determination of intracellular water space of cells in monolayer culture. Analytical Biochemistry 68, 537-544.

Lopez, R., Ronda-Lain, C., Tapia, A., Waks, S. B. \& Tomasz, A. (1976). Suppression of the lytic and bactericidal effects of cell wall-inhibitory antibiotics. Antimicrobial Agents and Chemotherapy 10, 697-706.

Mackaness, G. B. (1952). The action of drugs on intracellular tubercle bacilli. Journal of Pathology and Bacteriology 64, 429-446.

Mackaness, G. B. (1962). Cellular resistance to infection. Journal of Experimental Medicine 116, 381-406.

Magoffin, R. L. \& SPINK, W. W. (1951). The protection of intracellular brucella against streptomycin alone and in combination with other antibiotics. Journal of Laboratory and Clinical Medicine 37, 924-930.

Maier, T. \& Oels, H. C. (1972). Role of the macrophage in natural resistance to salmonellosis in mice. Infection and Immunity 6, 438-443.

MANDELL, G. L. (1973). Interaction of intraleukocytic bacteria and antibiotics. Journal of Clinical Investigation 52, 1673-1679.

Maw, J. \& Meynell, G. G. (1968). The true divi- sion and death rates of Salmonella typhimurium in the mouse spleen determined with superinfecting phage P22. British Journal of Experimental Pathology 49, 597-613.

Nathan, C. F. \& Root, R. K. (1977). Hydrogen peroxide release from mouse peritoneal macrophages. Dependence on sequential activation and triggering. Journal of Experimental Medicine 146, 1648-1662.

ReEs, R. J. W. \& HART, P. D’A. (1961). Analysis of the host-parasite equilibrium in chronic murine tuberculosis by total and viable bacillary counts. British Journal of Experimental Pathology 42, 83-88.

Richardson, M. \& HolT, J. (1962). Synergistic action of streptomycin with other antibiotics on intracellular Brucella abortus in vitro. Journal of Bacteriology 84, 638-646.

Seneca, H. \& Peer, P. (1966). Effect of antibacterials, antibiotics, enzymes and steroids on phagocytosis. Journal of the American Geriatrics Society 14, 187-199.

SolberG, C. O. (1972). Protection of phagocytized bacteria against antibiotics. Acta medica scandinavica 191, 383-387.

SuTER, E. (1952). The multiplication of tubercle bacilli within normal phagocytes in tissue culture. Journal of Experimental Medicine 96, 137-150.

VALTONEN, V. V. (1970). Mouse virulence of salmonella strains: the effect of different smoothtype $O$ side chains. Journal of General Microbio$\log y$ 64, 255-268.

Veale, D. R., Finch, H., Smith, H. \& Witt, K. (1976). Penetration of penicillin into human phagocytes containing Neisseria gonorrhoeae: intracellular survival and growth at optimum concentrations of antibiotic. Journal of General Microbiology 95, 353-363.

Ward, M. E., Glynn, A. A. \& Watt, P. J. (1972). The fate of gonococci in polymorphonuclear leukocytes: an electron microscope study of the natural disease. British Journal of Experimental Pathology 53, 289-294.

Wegener, W. S., Hebeler, B. H. \& Morse, S. A. (1977). Cell envelope of Neisseria gonorrhoeae: penicillin enhancement of peptidoglycan hydrolysis. Infection and Immunity 18, 717-725.

Wilder, M. S. \& Edberg, J. C. (1973). Interaction of virulent and avirulent Listeria monocytogenes with cultured mouse peritoneal macrophages. Infection and Immunity 7, 409-415. 